MATERIAєY

\title{
Raport Komitetu Narodowego Polskiego o sytuacji w I pułku strzelców polskich (lipiec 1917 r.)
}

W aktach Wydziału Wojskowego Komitetu Narodowego Polskiego (KNP) ${ }^{1}$, przechowywanych w zasobie Centralnego Archiwum Wojskowego ${ }^{2}$, opatrzony sygnatura CAW I.123.13.16, wśród innych materiałów znajduje się raport o stosunkach w 1 Pułku Strzelców Polskich ${ }^{3}$. Pisany ręcznie, opatrzony francuskim tytułem, liczacy 22 strony dokument poświęcony został omówieniu sytuacji kryzysowej spowodowanej usunięciem z pułku ponad 200 żołnierzy - byłych jeńców z armii pruskiej. Informuje o wizycie autora dokumentu w asyście trzech oficerów z Francusko-Polskiej Misji Wojskowej - w pułku oraz rozmowach, które tam odbył, następnie o rozmowach z usuniętymi z pułku żołnierzami, skierowanymi do pracy w parkach amunicyjnych na zapleczu linii frontowej. Wyniki owych rozmów oraz nasuwające się na ich podstawie spostrzeżenia $\mathrm{w}$ dalszej części dokumentu zostały poddane skrupulatnej analizie. Jakkolwiek wspomniany raport pozbawiony jest daty oraz podpisu autora, braki te daja się łatwo uzupełnić. Wszystko wskazuje, że autorem dokumentu był sam prezes KNP, Roman Dmowski. W swojej powojennej relacji relatywnie dużo miejsca poświęcił incydentowi przedstawionemu w sygnalizowanym dokumencie; przede wszystkim istotna jest informacja,

\footnotetext{
${ }^{1}$ Wydział Wojskowy KNP odpowiadał za organizację Armii Polskiej we Francji, utrzymując kontakt z Francusko-Polską Misją Wojskowa - jedną z agend francuskiego Ministerstwa Wojny, powołaną w czerwcu 1917 r. w związku z dekretem prezydenta Francji Raymonda Poincarégo, powołującego armię polska. Szefem Misji był francuski emerytowany wojskowy, gen. Louis Archinard.

2 Za zachętę oraz pomoc w korzystaniu z zasobu CAW pragnąłbym w tym miejscu serdecznie podziękować p. Krzysztofowi Widzińskiemu („Przegląd Historyczno-Wojskowy”).

${ }^{3}$ Wojskowe Biuro Historyczne (dawniej Centralne Archiwum Wojskowe - CAW), I.123.13.16, Sur les incidents au I Régiment des Chasseurs de l'Armée Polonaise et sur la nécessité de certaines réformes dans cette Armée, k. nlb.
} 
że wyjaśnieniem incydentu zajął się osobiście ${ }^{4}$. Na autorstwo Dmowskiego wskazują użyta w raporcie argumentacja, dobór słów, sposób formułowania myśli, wreszcie wnioski końcowe dotyczące oceny sytuacji, zbieżne z zawartymi we wspomnianej powojennej relacji, niezgodne zaś z wnioskami raportu Antoniego Potockiego, przygotowanego dla KNP kilka dni wcześniej ${ }^{5}$. Ostatni argument to charakter pisma.

Zakładając autorstwo Dmowskiego, można dość precyzyjnie określić czas powstania dokumentu. Raport Antoniego Potockiego nosił datę 3 VII 1918 r. Zgodnie z relacją Dmowskiego zareagował nań bezzwłocznie, zwracając się do dowództwa 4 Armii francuskiej o zgodę na umożliwienie mu wizyty w pułku. Doszła ona do skutku dwa dni później, 5 VII 1918 r. ${ }^{6}$ Biorąc pod uwagę nieobecność Dmowskiego na posiedzeniach KNP 6, 8 i 10 lipca $^{7}$, przyjąć można, że przesłuchania żołnierzy (w sumie kilkaset osób!), sporządzenie raportu, potem zaś dalsze działania na rzecz rozwiązania przedstawionego $\mathrm{w}$ nim problemu przypadały właśnie na ten okres. Później tego czasu nie miał za wiele: wprawdzie kolejne posiedzenie KNP, już z jego udziałem, odbyło się 17 lipca - jednak dwa dni wcześniej (15 lipca) armia niemiecka podjęła ostatnia już w I wojnie światowej próbę przełamania frontu, uderzając m.in. właśnie w pasie 4 Armii. Przyjąć można, że Dmowski musiał uporać się ze swoją praca wcześniej - po 15 lipca nie miałby możliwości poruszania się $\mathrm{w}$ pasie przyfrontowym.

Słów kilka o samym incydencie. W początkach czerwca 1918 r. żołnierze należący do jednostek tworzonej od roku armii polskiej we Francji znaleźli się na linii bojowej. 19 czerwca z patrolu nie wróciło 5 żołnierzy, 23 czerwca na stronę niemiecką przeszło 4, dwa dni później zaś to samo uczynił kolejny żołnierz. 26 czerwca Niemcy rozrzucili ulotki, wzywając pozostające w okopach wojsko do pójścia w ich ślady ${ }^{8}$, kusząc perspektywą końca wojny. W rezultacie batalion, w którym doszło do dezercji, został wycofany z pierwszej linii, następnie zaś na rozkaz dowódcy pułku zarządzono we wszystkich podległych mu jednostkach śledztwo, którym objęto wszystkich żołnierzy pochodzących $\mathrm{z}$ zaboru pruskiego, byłych jeńców z armii niemieckiej. W wyniku przeprowadzonych rozmów $2 / 3$ indagowanych - w sumie ponad 200 osób $b^{9}$ - usunięto ze służby, kierując - jako jeńców - do pracy w parkach amunicyjnych. 1 lipca

\footnotetext{
${ }^{4}$ R. Dmowski, Polityka polska i odbudowanie państwa. Z dodaniem memoriału „Zagadnienia środkowo- $i$ wschodnioeuropejskie" $i$ innych dokumentów polityki polskiej z lat 1914-1919, wyd. 2, Warszawa 1926, s. 296.

${ }^{5}$ Archiwum Akt Nowych (dalej: AAN), Komitet Narodowy Polski (dalej: KNP), 184 (Mf 20910), Raport Antoniego Potockiego z 3 lipca 1918 r. Sekretariat Jen. KNP. Korespondencja w sprawie armii polskiej.

${ }^{6}$ CAW, I.123.13.16, Sur les incidents..., k. 1.

7 AAN, KNP, 6 (Mf 20732), k. 1-6.

8 AAN, KNP, 184 (Mf 20910), Raport Antoniego Potockiego..., k. 36.

9216 żołnierzy wedle ustaleń Dmowskiego. CAW, I.123.13.16, Sur les incidents..., k. 7.
} 
dowódca pułku wydalił z jednostki kolejna grupę kilkudziesięciu żołnierzy zwerbowanych w Holandii - dokąd uciekli z Niemiec. Ze wspomnianego raportu Potockiego wynikało, że czystki nie doprowadziły do uspokojenia nastrojów w pułku. W dokumencie zostało odnotowane samobójstwo jednego z wydalonych żołnierzy, rozgoryczenie „Holendrów”, incydenty, do których dochodziło pomiędzy żołnierzami polskimi a francuskimi, niepewność dowództwa pułku, czy w wytworzonej sytuacji może odpowiadać za oddziały ${ }^{10}$, naciski francuskiego dowództwa domagającego się dalszych czystek... W tej sytuacji jego autor postulował czasowe wycofanie pułku z frontu. Usunięcie z niego byłych jeńców zaaprobował jako „konieczność wojskowa”, co więcej, w celu uniknięcia komplikacji w przyszłości sugerował pozbycie się żołnierzy pochodzacych z zaboru pruskiego także z pozostałych jednostek formującej się armii ${ }^{11}$.

„Gdyby - wspominał Dmowski - żołnierze z zaboru pruskiego usunęli się z naszego wojska - Niemcy mieliby argument, że Polacy poddani pruscy nie chca walczyć przeciwko Niemcom, a tym samym nie chcą należeć do Polski"12. To był powód, dla którego nie mógł on zaakceptować wniosków zawartych $\mathrm{w}$ raporcie, bez względu na to, że jego autor, z uwagi na wieloletnie wcześniejsze związki z Liga Narodowa ${ }^{13}$, z pewnością był dlań osobą zasługująca na zaufanie. Waga sprawy, uznanej za bezwzględny priorytet polityczny, sprawiła, że prezes instytucji posiadającej status oficjalnej reprezentacji narodowej oraz międzynarodowe uznanie zdecydował się osobiście podjąć się pracy, którą zwykle powierza się współpracownikom.

Równie niekonwencjonalny był przebieg wizyty Dmowskiego w jednostce. Ku oburzeniu dowództwa pułku delegaci KNP udali się nie do jego siedziby, ale do sztabu francuskiej 163 Dywizji, gdzie otrzymali przewodnika, po czym - jak wspominał autor interesujacego pamiętnika, ppor. Witold Trawiński - „chodzili od kompanii do kompanii, dopytując szeregowców i podoficerów o powody wycofania się z pułku Poznaniaków i Ślazaków”"14. Była to sytuacja bulwersująca: przyjęte przez prezesa KNP metody działania nie uwzględniały wojskowych obyczajów, jak i rygorów będących konsekwencją hierarchicznej struktury wojska. Można też spekulować na temat ich wpływu na dyscyplinę w pułku, chociaż ta ostatnia była i tak nadszarpnięta ostatnimi wypadkami. Wiadomo przecież, że działania w sytuacjach kryzysowych rządzą się odmienną logiką niż rutynowe - decydując się na nie, Dmowski mógł się obawiać utrudnień w uzyskaniu możliwości nieskrępowanych rozmów z żołnierzami. Wedle relacji Trawińskiego dowódca pułku, płk Julian Jasiński nie starał się nawet ukrywać niechęci do przedstawicieli władz cywilnych wtrącających

${ }_{10}$ AAN, KNP, 184 (Mf 20910), Raport Antoniego Potockiego..., k. 38.

${ }^{11}$ Ibidem, k. 39-41.

${ }^{12}$ R. Dmowski, op. cit., s. 298.

13 S. Kozicki, Historia Ligi Narodowej (okres 1887-1907), Londyn 1964, s. 25, 31, 282, 581.

${ }^{14}$ W.H. Trawiński, Odyseja Polskiej Armii Btękitnej, oprac. i wstęp W. Suleja, Wrocław 1989 , s. 256. 
się do spraw wojska - zgadzając się czynić wyjątek jedynie dla najwyższych władz Republiki Francuskiej (prezydenta oraz ministra wojny) - ale już nie KNP, któremu tworzona na ziemi francuskiej armia podlegała wprawdzie, ale faktyczny zakres uprawnień Komitetu był przedmiotem sporu. Jako że pułkownik uchylił się od spotkania, do wizyty w sztabie pułku ostatecznie nie doszło. Nie wpłynęło to na losy misji, która zakończyła się powodzeniem, umożliwiając przywrócenie do służby tych żołnierzy, którzy zgodzili się do niej wrócicic ${ }^{15}$.

Oceniany w kategoriach czysto militarnych omawiany epizod rzecz jasna nie miał wielkiego znaczenia, odnosząc się do zdarzeń, których widownię stanowił zaledwie jeden pułk. Jest on jednak niezwykle ciekawy z uwagi na to, że jak w soczewce skupiły się w nim problemy szersze, rozmaitej natury, od militarno-politycznych, po wiążące się raczej z cywilnymi aspektami polityki.

Kluczowe znaczenie miały kwestie dotyczace organizacji oraz funkcjonowania tworzonego we Francji wojska będącego terenem ścierania się wpływów kilku ośrodków - podporządkowanej francuskiemu Ministerstwu Wojny Francusko-Polskiej Misji Wojskowej, KNP, a do czasu także i ambasady rosyjskiej w Paryżu. Warto także przypomnieć, że francuskie władze wojskowe już od wiosny 1918 r. naciskały na przyśpieszenie szkolenia i skierowanie jednostek do walki, co spotkało się z oporami KNP obawiającego się wytracenia wojska. $\mathrm{W}$ tej sytuacji naciskał on tym mocniej na zdobycie satysfakcjonującej stronę polską deklaracji zarówno co do statusu tego wojska (jako siły sprzymierzonej, ale niebędącej częścią armii francuskiej), jak i poparcia polskiego programu terytorialnego (w tym rewindykacji kosztem Niemiec) ${ }^{16}$. Wysyłając pułk do walki, Francuzi próbowali przejść do porządku dziennego nad obiekcjami ze strony KNP, w tym i zablokowaniem przezeń - przy braku innych instrumentów nacisku - uroczystości wręczenia mu sztandaru. Nie było to bez skutku dla wytworzenia się sytuacji kryzysowej - opisując drogę jednostki na front, ppor. Trawiński akcentował trwająca niemal do ostatniej chwili niepewność co do losów pułku, który wprawdzie ostatecznie dotarł na front w całości, wcześniej jednak Francuzi myśleli raczej o rozwiązaniu jednostki i uzupełnieniu jej batalionami poszczególnych pułków 163 Dywizji... ${ }^{17}$

Tworzenie wojska napotkało opór także w obozie polskim, gdzie próbowały przeciwdziałać środowiska orientujące się na Niemcy. Jest możliwe, że miało to swoje skutki podczas wydarzeń opisanych $\mathrm{w}$ raporcie - w każdym razie

${ }^{15}$ R. Dmowski, op. cit., s. 297-298.

${ }^{16}$ Polityka ta, przypisywana słusznie Dmowskiemu, budziła wątpliwości i oskarżenia o megalomanię także w obozie polskim: o „męczenie Francuzów” oskarżał Dmowskiego Wincenty Lutosławski (list z 18 V 1918 r.); współpracujący zaś blisko z Ignacym Paderewskim Zygmunt Iwanowski (list z 27 V 1918 r.) podejrzewał Dmowskiego o nielojalność wobec Francji i wyczekiwanie „która strona wygra”. Archiwum polityczne Ignacego Paderewskiego, t. I: 1890-1918, oprac. W. Stankiewicz, A. Piber, Wrocław 1973, s. 359, 507.

17 W.H. Trawiński, op. cit., s. 223-224. 
Dmowski był o tym przekonany ${ }^{18}$. Z punktu widzenia znacznej części oficerów francuskich - a ci dominowali w pułku - istotne było, że napotkali problemy, w których rozwiązywaniu doświadczenie nabyte podczas służby w koloniach okazywało się mało przydatne. Źródło wytwarzającego się dystansu stanowiła nie tylko nieznajomość języka polskiego przez znaczną część kadry, niekiedy także przejawy przykro przez Polaków odbieranej nonszalancji z jej strony ${ }^{19}$, ale i obawy przed rozpolitykowaniem wojska, będące poniekąd także skutkiem rozgrywek wokół niego, przede wszystkim jednak zjawiskiem mającym związek z trybem rekrutacji w drodze dobrowolnych zgłoszeń. Z motywacja patriotyczną wiązała się nieuchronnie także polityczna aktywność żołnierzy i nie było na to rady. To co potencjalnie mogło być siła tej armii, bywało jej słabością w sytuacji, gdy na miejscu okazywało się, że wyśnione polskie wojsko wygląda inaczej, niż sobie wyobrażano. Napięcia ujawniały się na tle stosunku do francuskiej kadry, ale i kolegów pochodzenia żydowskiego, $\mathrm{z}$ reguły wywodzacych się z armii francuskiej, podejrzewanych o dekownictwo i defetyzm ${ }^{20}$. Inny konflikt, ujawniony w pierwszych miesiacach tworzenia armii, wiązał się z próbami przejęcia nad nią kontroli przez ambasadę rosyjską w Paryżu. Rezultatem napięć były liczne incydenty odnotowywane we wspomnieniach Trawińskiego - z próbą dezercji grupy ponad 40 „Holendrów” wiosną 1918 r. włącznie... ${ }^{21}$

Czynnik frustrujący stanowiła także niepewność jutra, zrozumiała w przypadku armii pozbawionej własnego państwa. Jej perspektywy były ściśle związane z losami wojny. W przypadku klęski aliantów uzyskanie dla wojska statusu siły samodzielnej, forsowane przez KNP, zemściłoby się na żołnierzach. Pozostaliby na przysłowiowym lodzie, pozbawieni - w przypadku ochotników będących poddanymi niemieckimi - nawet możności powrotu do domu ${ }^{22}$. Dzisiaj

${ }^{18}$ R. Dmowski, op. cit., s. 298. Czasem sprzeciw ów przyjmował formy drastyczne: przedstawiciele polskiej misji wojskowej w Londynie w drugiej połowie maja 1918 r. otrzymali list z pogróżkami, że jeśli „panowie szlachta” będą nadal posyłać ludzi do „szlachtuza na zabicie", sami straca życie w zamachu bombowym. CAW, I.123.12.10, k. nlb., datowany na $17 \mathrm{~V} 1918$.

19 Jednym z zapadających w pamięć charakterystycznych obrazków, odnotowanych w relacji Witolda Trawińskiego, był - z czasów formowania armii - widok wieszaków przy wyjściu z siedziby Francusko-Polskiej Misji Wojskowej, gdzie obok siebie wisiały rogatywki i francuskie kepi: pierwsze noszone na terenie jednostki, drugie zaś zakładane przez oficerów przy wyjściu do miasta - by nie narażać się na ulicy na pytanie, „co to za wojsko”. W.H. Trawiński, op. cit., s. 186.

${ }^{20}$ Ibidem, s. 177, 179.

${ }^{21}$ Ibidem, s. 198.

22 Argument ten pojawił się już w 1917 r., gdy aktywne w Paryżu środowiska polskiej lewicy podjęły krytykę dekretu prezydenta Francji, a potem poczynań związanych z tworzeniem wojska. Zob. „Zjednoczenie i niepodległość”. Związek Komitetów propagandy, Okólnik nr 23, Paryż 15 czerwca 1917 r., w: KNP, 178 [Mf 20904], Sekretariat Jeneralny KNP. Pisma dot. armii pol. we Francji, k. 66. Por. St. Jasieńczyk, Armia Polska we Francji, „Głos Polski” R. I, 27 VII 1917, nr 1 (ibidem, k. 119). 
wiemy, że seria niemieckich ofensyw, prowadzona od wiosny 1918 r., zakonczyła się katastrofa. Współczesnym wszakże mogło się wydawać, że przejęcie przez Niemcy inicjatywy - po 4 latach militarnego impasu - jest zwiastunem zbliżającego się rozstrzygnięcia. Trawiński wspominał „strachajłów” oraz „złe duchy”, wieszczace upadek Francji ${ }^{23}$. W atmosferze niepokoju o przyszłość tym silniej oddziaływać mogły wątpliwości co do polskiego charakteru wojska, irytacja przejawami nonszalancji i bałaganu - owocując irytacją i pragnieniem wycofania się. Jest wysoce prawdopodobne, że sytuacja na froncie rzutowała na postawy żołnierzy, którzy odmówili dalszej służby w polskim wojsku, możliwe też, że gdyby Dmowski przeprowadził rozmowy z usuniętymi z pułku byłymi jeńcami miesiąc później, po klęsce ostatniej z niemieckich ofensyw, kategorycznych odmów byłoby mniej. Analizujacc i klasyfikując postawy byłych jeńców, tego akurat czynnika nie uwzględnił w raporcie, co ze ściśle merytorycznego punktu widzenia stanowiło zapewne jego słabość. Biorąc pod uwagę wrażliwość adresatów raportu już niekoniecznie: rozsądniej było nie dostarczać argumentów, które choć w gruncie rzeczy zrozumiałe, mogły posłużyć do oskarżeń żołnierzy polskich o koniunkturalizm.

Omawianie zawartości dokumentu wydaje się zbędne. Na kilka elementów warto jednak zwrócić uwagę. Najważniejszy to oczywiście koncentracja uwagi autora na problemie byłych jeńców. Drugi istotny element to okazana przez niego gotowość brania na siebie ryzyka związanego z przedstawianiem wniosków, które niekoniecznie musiały się adresatom raportu podobać. Dotyczy to przede wszystkim próby usprawiedliwienia decyzji ponad setki żołnierzy, którzy mimo nalegań odmówili dalszej służby, a i sugestii, że wpływ francuskich oficerów na armię jest nadmierny i powoduje negatywne skutki. Problem odrębny to zawarte w dokumencie negatywne opinie dotyczące Żydów, które dziś mogą razić - jakkolwiek podobnych w owym czasie w odniesieniu do armii „błękitnej” istniało więcej ${ }^{24}$. Nawet gdyby uznać je za przejaw li tylko uprzedzeń autora raportu, to jednak panował nad nimi, dawkując informacje

${ }^{23}$ W.H. Trawiński, op. cit., s. 206, 208. Po drugiej stronie frontu charakterystyczne spostrzeżenia czynił Polak służący w armii pruskiej, Józef Iwicki: te z wiosny 1918 r., chociaż dokumentujace starania o zachowanie dystansu wobec triumfalnego tonu propagandy niemieckiej, brzmiały jednak znacząco inaczej niż pochodzące sprzed pół roku (jesień 1917 r.), kiedy akcentował brak możliwości osiagnięcia przewagi nawet przez stronę angażująca największe środki. Z myśla o Niepodlegtej. Listy Polaka, żotnierza armii niemieckiej, $z$ okopów I wojny światowej (1914-1918), wybór, wstęp i oprac. A. Juzwenko, Wrocław 1978, s. 222, 250, 257, 259.

24 „Mniej więcej do początku 1918 r. ta Judeo-Polska [...] raczej nas ośmieszała - wspominał przebywający wówczas w stolicy Francji Hipolit Korwin-Milewski - Potem, gdy z zezwolenia Wilsona posypali się ochotnicy amerykańscy, jeńcy Polacy z niemieckiego i austriacko-włoskiego frontu, to wojsko dorosło do kilkudziesięciu tysięcy ludzi i w decydującej chwili (18 lipca 1918 r.) walecznie się popisało [...]". H. Korwin-Milewski, Siedemdziesiat lat wspomnień (1855-1925), Poznań 1930, s. 236. Istniejace w oddziałach napięcia potwierdzała i relacja Trawińskiego. Problem na pewno zasługuje na studium monograficzne. 
tak, aby były strawne dla Francuzów. Ilustrują to poprawki w tekście: zarówno skreślenia, jak i dokonywane ołówkiem sugestie zmian.

Rzecz jasna, prześledzenie całej drogi wytworzonego dokumentu, jak i jego wszystkich skutków wymagałoby kwerendy w archiwach francuskich. Ale i w postaci surowej jest on bardzo interesujacy. Poza wszystkimi innymi względami znakomicie się go czyta. Jest on dziełem człowieka sprawnie posługującego się piórem, potrafiącego przedstawiać sprawy bardzo skomplikowane językiem prostym, w sposób przykładnie klarowny. Dla historyka wojskowości najciekawszy może być opis samego incydentu, bez względu na jego ograniczoną skalę. Biorac wszakże pod uwagę, że intencję autora stanowiło nie tyle przedstawienie przebiegu zdarzeń, ile upomnienie się o rodaków z zaboru pruskiego, dla rekonstrukcji wydarzenia pożądane byłoby zestawienie załaczonego raportu z wcześniejszym, autorstwa Antoniego Potockiego. Ciekawsze jednak wydają się polityczne implikacje incydentu, związane zarówno ze skomplikowanym układem podległości, w którego obrębie funkcjonowało wojsko, jak i sporami w obozie polskim. Można w nim także widzieć przyczynek do szerszego zagadnienia relacji między władzami wojskowymi a cywilnymi - kwestii o znaczeniu fundamentalnym w państwach demokratycznych. Jakkolwiek w Polsce międzywojennej akcentowano zazwyczaj niebezpieczeństwa „upartyjnienia” armii, przedstawiony w dokumencie incydent dowodziłby raczej niecelowości pozostawiania wojsku zbyt wielkiego zakresu swobody.

Przede wszystkim jednak omawiany raport stanowi zapis polityki paryskiego KNP i jej prezesa (poniekąd także przyczynek do biografii tego ostatniego), informujacc o hierarchii priorytetów, metodach działania, sposobie budowania argumentacji, dopasowywania jej do mentalności odbiorców. Wszystko pokazane niejako „od kuchni”. Wygląd dokumentu wskazuje bowiem, że mamy do czynienia raczej z brudnopisem niż postacia finalna, przeznaczona do przetłumaczenia na język francuski i przepisania na maszynie. Jest w nim trochę skreśleń (chociaż w sumie niewiele), są też znaki ołówkiem, zarówno redakcyjne, jak i skreślenia, nanoszone już po napisaniu całości. Dzięki nim możemy dowiedzieć się, jak raport powstawał; jak jego autor dobierał argumenty, jak wiązał je ze znanymi faktami. Takich możliwości nie dałby tekst $\mathrm{w}$ postaci finalnej.

Przygotowując dokument do druku, aby ułatwić lekturę współczesnemu czytelnikowi, uwspółcześniono pisownię (Holandyi - Holandii, z pośród - spośród, jenerał - generał). Rozwinięto skróty tam, gdzie ich odczytanie mogło stanowić problem. Gdy idzie o skreślenia, to nie odnotowywano ich tam, gdzie w grę wchodziły jedynie drobne poprawki stylistyczne dokonywane przez autora $\mathrm{w}$ trakcie pisania. Wskazano je natomiast, gdy mogły w stopniu istotniejszym rzutować na wymowę przekazu. Dotyczy to m.in. dłuższego passusu traktującego o oporze żołnierzy broniących się przed wzięciem do niewoli, w tym także jednej z osób sfotografowanych na ulotce niemieckiej. Chociaż pod wieloma względami może on budzić zainteresowanie, wersja 
finalna jednak była bardziej zwarta i brzmiała lepiej. Odnotowano także, jeśli skreślenie, dokonane ołówkiem, sugerowało możliwość późniejszej ingerencji autora $\mathrm{w}$ tekst.

Krzysztof Kawalec

Wrocław

\section{Sur les incidents au I Régiment des Chasseurs de l'Armée Polonaise et sur la nécessité de certaines réformes dans cette Armée ${ }^{25}$}

W końcu czerwca r.b. w pierwszym pułku strzelców polskich, przydzielonym do IV armii i stojącym na pierwszych pozycjach, zaszły wypadki, które odsłoniły bardzo słabe i niebezpieczne strony w ustroju Armii Polskiej i zmusiły Komitet Narodowy do wejrzenia głębiej w jej położenie.

Zawiadomiony o fakcie przejścia kilku strzelców do nieprzyjaciela i o dokonaniu $\mathrm{w}$ następstwie oczyszczenia pułku z żywiołów podejrzanych o chęć dezercji, mianowicie żołnierzy pochodzacych z jeńców wojennych, udałem się dn. 5 lipca w towarzystwie trzech oficerów Misji Wojskowej Francusko-Polskiej do IV Armii i przeprowadziłem ścisłą ankietę, która ustaliła następujące fakty:

D.[Dnia] 19 czerwca patrol I pułku w liczbie 30 ludzi stracił 6 ludzi z 10 kompanii, którzy znikli i z których jeden powrócił w następstwie. Z tych sześciu trzech było ochotników z Ameryki, dwóch b. jeńców, i jeden, ten mianowicie, który wrócił, spośród zwerbowanych w Holandii. Co do pierwszych trzech, pochodzących z Ameryki, wkrótce znalazł się dowód, że znajduja się w ręku nieprzyjaciela. Niemcy ich obfotografowali i wydrukowali w ich imieniu odezwę, zredagowana w okropnym języku niemiecko-polskim, jakim często Żydzi w Polsce mówiąa ${ }^{26}$, wzywająca żołnierzy do dezercji. Odezwę tę, na której znajdowały się fotografie owych trzech strzelców, podających się za dobrowolnych dezerterów, przerzucono do okopów polskich.

Ankieta moja wykazała, że nie ma żadnych danych do uważania owych strzelców istotnie za dezerterów. Przeciwnie, uczestnicy patrolu zeznali, iż słyszeli podczas spotkania z nieprzyjacielem, jak sierżant Sokołowski, jeden $\mathrm{z}$ trzech obfotografowanych, zachęcał towarzyszy do walki, wołając: „nie dajmy się, bracia!”. To, że Niemcy sfabrykowali w ich imieniu odezwę, niczego nie dowodzi.

Fakt, że obfotografowani zostali tylko trzej strzelcy pochodzacy z Ameryki, gdy obok nich znikło jeszcze dwóch pochodzacych z jeńców, pozwala przypuszczać, że ci dwaj padli w starciu, albo po wzięciu do niewoli, zostali natychmiast rozstrzelani.

\footnotetext{
${ }^{25}$ W sprawie incydentów w I Pułku Strzelców Armii Polskiej i potrzeby pewnych reform $\mathrm{w}$ tej armii.

${ }^{26}$ To wtrącenie zostało zamazane ołówkiem.
} 
Co do ostatniego, który powrócił, padło w pułku podejrzenie, że był u Niemców i ci go wysłali z powrotem do okopów polskich. Ja osobiście poddałem go dłuższemu badaniu co do jego przeszłości i co do sposobu spędzenia 36 godzin nieobecności, i wcale nie doszedłem do wniosku, żeby to był człowiek podejrzany. Opowiadanie jego o sposobie, w jaki mu się udało ukryć w okopach, ma wszelkie cechy prawdopodobieństwa, co najwyżej z tendencja, dosyć zwykła, upiększania własnych przygód.

Natomiast 23 czerwca znikło z okopów czterech strzelców z 7 kompanii, co do których fakt dezercji można uważać za ustalony ${ }^{27}$. Spośród tych czterech strzelców trzech pochodziło z jeńców z armii niemieckiej (P.R.) ${ }^{28}$, jeden zaś był ochotnikiem z Ameryki, byłym poddanym austriackim. Ten ostatni nazwiskiem Chmiel [podkreślenie autora raportu], znany był w Ameryce, jako internacjonalista i przeciwnik armii polskiej. Żołnierze zeznali, że podczas pobytu $\mathrm{w}$ armii agitował on $\mathrm{w}$ duchu przeciwnym armii między towarzyszami. Pozwala to przypuścić, że był on inicjatorem dezercji, tym bardziej, że w dniu zniknięcia widziano go, jak oglądał rów (boyau), prowadzący do okopów niemieckich. Zrozumiała jest też dezercja $\mathrm{u}$ jednego $\mathrm{z}$ b. jeńców, Kłokockiego [podkreślenie autora raportu], który, jak zeznania stwierdzaja, był od chwili zaangażowania się malkontentem, nie znosił służby wojskowej, a jego niezadowolenie zwiększał fakt, że był ciagle głodny, odznaczał się bowiem nienormalnie wielkim apetytem. Powtarzał też ciagle przed kolegami słowa: „Ze mnie nie zrobią żołnierza”. Dziwna jest natomiast dezercja dwóch pozostałych strzelców, b. jeńców, którzy byli bardzo dobrymi żołnierzami, a jeden $\mathrm{z}$ nich miał być nawet zaawansowany na sierżanta.

$\mathrm{Z}$ tej dezercji wyrosła kwestia P.R. w pierwszym pułku, której nadano bardzo niebezpieczne rozmiary.

Wszczą ją raport dowódcy pułku do generała dowodzącego IV armia, w którym znalazł się jeden błędny szczegół. Mianowicie powiedziano w nim, że z 4 dezerterów trzej byli P.R. z armii niemieckiej, a czwarty, Chmiel, jakkolwiek przybył z Ameryki, to jednak dawniej, przed wojna, służył też w armii niemieckiej. Tymczasem Chmiel, pochodził z Polski austriackiej i nigdy przedtem w żadnej armii nie służył. Ten błąd pomógł do uogólnienia, że może pochodzący z niemieckiej Polski stanowią kategorię żołnierzy niepewnych, grożących liczną dezercją ${ }^{29}$. Zaangażowanie [nieczytelne] ich

${ }^{27}$ Skreślony dłuższy passus: „[...] podczas spotkania z Niemcami zachęcał towarzyszy do walki okrzykiem: «nie dajmy się, bracia!», co jest najlepszym dowodem, że wpadł w ręce nieprzyjaciela wbrew swej woli. Nic nie przeszkodziło Niemcom obfotografować go wraz z dwoma towarzyszami i wydać w ich imieniu odezwy, napisanej żydowsko-polskim językiem, zachęcającej żołnierzy polskich do dezercji i przerzuconej do okopów polskich. W wypadku zniknięcia 4 strzelców d. [dnia] 23 czerwca mamy niezawodnie do czynienia z dezercją".

${ }^{28}$ Skrót z j. franc.: prisonnier recruté.

${ }^{29}$ Pionowa kreska ołówkiem mogła oznaczać polecenie rozpoczęcia akapitu w wersji ostatecznej - przeznaczonej do przepisania na maszynie i przetłumaczenia. 
do armii polskiej dowódca pułku i jego otoczenie tłumaczyli sobie chęcia poprawy losu i nadzieja, że nie pójdą na front (w pułku krążyły wieści, że przy werbowaniu jeńców zapewniano ich, że nie będą użyci do służby frontowej).

Po otrzymaniu raportu generał dowódca IV Armii polecił dowódcy pułku każdego P.R. indywidualnie zapytać, czy chce się bić przeciw Niemcom, i tych, którzy dadzą odpowiedź negatywna, usunać z pułku, żeby uniknąc dalszych dezercji. Ten rozkaz byłby całkiem uzasadniony i gdyby go ściśle wykonano, byłby tylko pożyteczny. Niestety wykonano go zupełnie inaczej.

W rezultacie przeszło 140 strzelców z kategorii P.R. wystapiło „dobrowolnie" z pułku. Do nich dołączono ludzi zwerbowanych w Holandii. Wreszcie po dokonaniu tej samej operacji w szwadronie kawalerii i w kompanii saperów, stojących w sąsiedztwie, liczba usuniętych wyniosła 216 P.R. i 40 zwerbowanych w Holandii ${ }^{30}$.

Przed rozpoczęciem ankiety $\mathrm{w}$ tej sprawie uderzył mię fakt, że gdy z I i II batalionu I p. strzelców prawie wszyscy P.R. wyszli (zostało w każdym z tych batalionów tylko po 6-7), w III batalionie prawie wszyscy w liczbie około 60 pozostali (opuściło szeregi tylko 7). Świadczył on, że były jakieś miejscowe warunki w batalionach wpływajace na stosunek P.R. do armii.

Drugim znamiennym faktem było, że jeden z usuniętych P.R. odebrał sobie życie, pozostawiając list, w którym oświadcza, że nie może przeżyć takiego zbeszczeszczenia jak usunięcie z armii polskiej; trzem innym musiano broń wyrwać z ręki, gdy chcieli zrobić to samo. Świadczy to, że ludzie byli usuwani z szeregów nie całkiem dobrowolnie i że usuwano między innymi żołnierzy odznaczających się goracym patriotyzmem i wysokim poczuciem honoru.

Ankieta moja utwierdziła mię w tym przekonaniu.

Z 216 P.R. usuniętych z szeregów 114 przy pierwszym badaniu przez mnie oświadczyło, że nie chcą usuwać się z armii, że pragnieniem ich jest być żołnierzami, bić się za Polskę i bić się przede wszystkim przeciwko Niemcom. Usunięto ich albo wbrew ich woli, albo doradzano im wyjście i zrozumieli, że się chca ich pozbyć, albo wreszcie wyszli, bo nie mogli znieść atmosfery podejrzenia, którą ich otoczono, bo wreszcie obrażano ich podejrzeniami. Wielu zeznało, że zaczęto od tego, że ich rozbrajano, odprowadzano pod strażą do pułkownika, a tam oświadczono, że nie sa żołnierzami, tylko jeńcami, i że, jeżeli chca, mogę się na nowo do wojska polskiego angażować. W innych wypadkach usunięci zeznali, iż oficer powiedział im, że władze niemieckie znają ich prawdziwe nazwiska (P.R. służą pod przybranymi nazwiskami), że rodziny ich $\mathrm{w}$ Polsce niemieckiej ulegna prześladowaniu z ich powodu i że mają wybierać między rodziną a ojczyzną. Zrozumieli to jako namowę do opuszczenia szeregów, jako chęć pozbycia się ich.

${ }^{30}$ Raport A. Potockiego podaje inne liczby: „ponad 200” byłych jeńców oraz 55 „Holendrów” (k. 37). 
Pozostali 102 P.R., usunięci z pułku, oświadczyli, że po tym, co zaszło, do wojska polskiego już nie wróca, gdyż nie chca się dalej narażać na podobne traktowanie. $\mathrm{O}$ ile mi wiadomo, żaden nie powoływał się na to, żeby go angażowano do innej służby, jak frontowa, i mówili, że przyszli po to, aby się bić przeciw Niemcom, ale że ich obrażono podejrzeniami.

U wszystkich zreszta zarówno u tych 114, którzy oświadczyli, że chca służyć w armii polskiej, jak i u 102, którzy tej chęci nie okazali, zauważyłem w mniejszym lub większym stopniu stan rozczarowania, pewnego zniechęcenia, brak wiary w to, żeby ta armia była naprawdę polska, i nieufność względem zwierzchników.

To samo zauważyłem przy badaniu tych P.R., którzy pozostali w pułku, w szczególności w III batalionie, z którego, jak wspomniałem, wyszło tylko kilku. Tam sierżant, przemawiający głównie w ich imieniu, człowiek b. inteligentny i robiący wrażenie dzielnego żołnierza, powiedział mi: „My byśmy także byli odeszli z innymi, bo nasze położenie tu jest upokarzajace i obrażani jesteśmy podejrzeniami, uważani niemal za Boszów ${ }^{31}$, nie odwołują się do naszego patriotyzmu, do naszego poczucia honoru, przemawiaja do nas tylko karami. Nie czujemy tego, żebyśmy byli w wojsku polskim: panuje w pułku język francuski, a w biurach siedzą sami Żydzi. Zostaliśmy tu tylko, żeby bronić honoru Polaków poznańskich, żeby pokazać, że jesteśmy takimi Polakami jak inni. W obronie swego honoru życie swoje oddamy!".

Mam wrażenie, że ten sierżant głównie sprawił, że P.R. w pierwszym batalionie na ogół pozostali. Znalazł się w jego osobie człowiek, który umiał się odwołać do patriotyzmu i poczucia honoru żołnierzy.

Jako człowiek, który zna dobrze wszystkie części Polski i ich ludność i zdaje sobie sprawę z wartości wszystkich kategorii żołnierzy w Armii Polskiej, pozwalam sobie określić to wyeliminowanie P.R. z dwóch batalionów I pułku strzelców, ze szwadronu konnicy i z kompanii saperów, jako wynik tragicznego nieporozumienia, w którym możliwe jest nawet, że działała zła wola, chęć szkodzenia armii i sprawie polskiej. Szkoda tu wyraża się w następującym:

1. Usunięto z wojska najpatriotyczniejszy żywioł polski, najgłębiej uświadomiony w swej polskości, lud bowiem w Poznańskiem odznacza się najbardziej świadomym siebie patriotyzmem, wypróbowany w codziennej walce z niemczyzna, w której bierze udział cała ludność polska pod panowaniem niemieckim.

2. Usunięto z szeregów ludzi najinteligentniejszych, najbardziej oświeconych, część bowiem Polski, należąca do Niemiec, wyróżnia się wysokim stanem oświaty mas, wśród których nie istnieją wcale analfabeci.

3. Usunięto wybornego, najbardziej wyćwiczonego żołnierza, tego mianowicie, który przed przyjściem do armii polskiej przeszedł już szkołę armii niemieckiej i który ma mniej lub więcej doświadczenia wojennego.

31 „Bosz”, franc. le Boche - pogardliwe określenie Niemca podczas I wojny światowej. 
4. Zrobiono polityczna robotę „pour le roi de Prusse” ${ }^{32}$, gdyby bowiem cała armia polska poszła w ślady I pułku i dokonała podobnej „epuracji” ${ }^{33}$, Niemcy na konferencji pokojowej podałyby ten fakt, jako dowód, że ich poddani polscy nie chcieli się bić przeciw Niemcom, że są sami lojalnymi Niemcami, że zatem Poznań jest ziemia niemiecka.

Źródłem tego nieporozumienia jest z jednej strony psychologia samych P.R., z drugiej - stan rzeczy w I pułku strzelców i w ogóle w Armii Polskiej.

Polaków, jeńców z armii niemieckiej, którzy się zaangażowali do wojska polskiego, można podzielić na dwie kategorie: jedni z dużym temperamentem bojowym, z entuzjazmem do walki o wolność ojczyzny, z pragnieniem zemsty na Niemcach, za krzywdy wyrządzone Polsce; drudzy, bądź ze słabym temperamentem, bądź zmęczeni wojną i pobytem w obozach jeńców, bądź posiadający liczne rodziny w kraju pod panowaniem niemieckim, którzy zapału do boju nie mając, zaciagnęli się tylko z poczucia obowiązku, mówiącego im, że kiedy jest wojsko polskie, to Polak musi w nim służyć, a w niektórych wypadkach, żeby po prostu wyjść z ciężkiego i upokarzającego położenia $\mathrm{w}$ jakim się znajdowali, jako jeńcy. Możliwe jest, że między Polakami wkradł się jeden drugi Niemiec, mówiący po polsku, szpieg lub agent-prowokator (jeden z P.R. zeznał, że on i jego towarzysze sami ostrzegali oficera rekrutujacego przed niektórymi jeńcami, że jednak rekrutacja nie była robiona dość ściśle). Wszyscy ci Polacy z armii niemieckiej byli materiałem bądź na pierwszorzędnych, bądź na lojalnych w każdym razie żołnierzy wojska polskiego, i wszyscy rozumieli, że angażują się do walki z Niemcami.

Znalazłszy się w szeregach Armii Polskiej, rozczarowali się oni w znacznej mierze zarówno co do polskości tej armii, jak i co do jej wartości, jako armii, wreszcie znaleźli się w niej w dosyć przykrym położeniu:

1. Raziła ich przewaga języka francuskiego i oficerów nie rozumiejacych po polsku.

Trzeba pamiętać, że walka polsko-niemiecka w Poznańskiem i w innych prowincjach polskich pod panowaniem niemieckim, jest przede wszystkim walka o język ojczysty. Stąd Polak tamtejszy jest niesłychanie czuły na punkcie języka. Prosty żołnierz, nie wdając się w powody, dla których język francuski odgrywa znaczną rolę w wojsku polskim, uważa to za narzucanie obcego języka, za akt wrogi polskości. Uspokoiłoby go, gdyby widział coraz większy postęp na rzecz języka polskiego, ale postępu tego nie widzi.

2. Uderzało go, że oficerowie nie mówiący po polsku, zajmuja stanowiska wyższe, że dowódcy otaczaja się oficerami i podoficerami nie mówiącymi po polsku, podczas gdy oficerowie polscy z armii rosyjskiej lub z Ameryki sa traktowani jako żywioł podrzędny.

${ }^{32}$ Dosłownie: dla pruskiego króla; w tym wypadku: w interesie niemieckim.

${ }^{33}$ Franc. épuration, po polsku w tym kontekście: czystka. 
3. Przeraziła go obecność i znaczna stosunkowo ilość Żydów w wojsku polskim, zajmujących stanowiska oficerów, podoficerów, a przede wszystkim sekretarzy i rachmistrzów.

W Polsce niemieckiej, w walce Polaków z Niemcami wszyscy bez wyjątku Żydzi stoją po stronie Niemców przeciw Polakom i nie ma ani jednego, który by się za Polaka uważał lub polskość popierał. Stąd Polak tamtejszy uważa wszystkich Żydów bez wyjątku za wrogów Polski. Spotykając Żyda w wojsku polskim, uważa go za przebranego wroga, za takiego, który każdej chwili to wojsko zdradzi; obecność Żydów w wojsku jest w oczach jego dowodem, że to nie jest wojsko polskie.

4. Uderzył go w tym wojsku brak dostatecznego szacunku dla polskości.

Niektórzy oficerowie i podoficerowie z armii francuskiej, choć sa pochodzenia polskiego, pozwalaja sobie obrażająco się wyrażać o Polsce i Polakach i nie ukrywają swej pogardy dla języka polskiego, polskich zwyczajów itp.

5. Czuł się dotknięty sposobem postępowania z żołnierzami, nie liczącym się z ich godnością osobista.

Do wojska polskiego przeszło wielu oficerów i podoficerów z Legii Cudzoziemskiej, którzy stamtąd przynieśli system dyscypliny i metody postępowania z ludźmi. Tymczasem Polak z Polski niemieckiej jest typem wyżej rozwiniętym moralnie od przeciętnego mieszkańca innych części Polski i ma on wysoko rozwinięte poczucie honoru i godności osobistej. Wspomniany wyżej sierżant z III batalionu, który tam pozostał i kolegów swych zatrzymał w wojsku polskim, powiedział mi: „Byłem w wojsku pruskim, tam jako Polak byłem podejrzewany i obserwowany, ale zapewniam Pana, że jako człowiek byłem więcej szanowany, niż tu w wojsku polskim".

6. Jako żołnierz, który przeszedł twardą szkołę armii pruskiej, krytykuje on wojsko polskie, zwraca uwagę, że za wiele czasu zmarnowano, którego można było użyć na naukę i wyćwiczenie żołnierza, że pułk poszedł na front nie przygotowany należycie, a co najważniejsze, że między oficerami nie ma jedności, że istnieje przepaść, dzieląca oficerów francuskich od pozostałych, i to wartość wojska polskiego, jako wojska, w jego oczach obniża. Wreszcie

7. I pułk strzelców był od początku izolowany od reszty wojska polskiego, nie miał wspólnego z nia dowództwa, wysłany został na front nawet bez sztandaru $^{34}$. To pozwoliło się rozwinąc wśród żołnierzy przekonaniu, że armii polskiej nie będzie, że to co zostało uformowane, przydzielone będzie do armii francuskiej, jako legia cudzoziemska.

$\mathrm{Z}$ tym przekonaniem spotkałem się jako z bardzo rozpowszechnionym wśród żołnierzy I pułku, w szczególności wśród P.R. Muszę dodać, że natrafiłem na ślady agitacji, przenikajacej z zewnątrz do pułku, agitacji, która to pojęcie szerzy, w celu zniechęcenia żołnierzy, i która ma niezawodnie źródła niemieckie.

Wszystko to sprawiło, że wśród żołnierzy, a w szczególności wśród P.R. nastapiło rozczarowanie i zniechęcenie. Odbiło się ono najsilniej na

${ }^{34}$ Skreślone: „polskiego”. 
tych P.R., którzy bez zapału, jeno z poczucia obowiązku wstapili do wojska, dlatego, że to wojsko polskie. Gdy doszli do przekonania, że to nie jest wojsko polskie, że wojska polskiego nie ma, uznali swój krok za fałszywy i zaczęli myśleć o wydostaniu się z tego [nieczytelne ${ }^{35}$ ] fałszywego położenia.

Z drugiej strony stosunek oficerów do P.R. nie był taki sam, jak do innych żołnierzy. Razili oni oficerów, jako ludzie bardziej niepodlegli, bardziej szanujący się i domagający się dla siebie szacunku; raziło ich porównywanie przez nich tego, co się robi w armii polskiej z tym, co było w niemieckiej; wreszcie uderzała ich nieprzyjemnie wojskowa tresura pruska tych ludzi. Przy swojej nieznajomości Polski, oficerowie z armii francuskiej widzieli w tym cechy Boszów, i bardzo łatwo wytworzyli sobie teorię, że Polacy z Poznańskiego to sa pół-Bosze, którą to teorię często z ich ust słyszałem.

$\mathrm{Na}$ dodatek Żydzi będący w armii polskiej, przy izolacji tych oficerów od kolegów polskich, odgrywających względem nich rolę informatorów, widząc w P.R. swoich wrogów (ci bowiem swej nieufności do Żydów nie ukrywali) usposabiali oficerów francuskich przeciw P.R., wskazując na nich jako na ewentualnych zdrajców.

To wszystko otoczyło żołnierzy z kategorii P.R. atmosferą nieufności i podejrzeń, atmosfera, która stał się dla nich nieznośna. Jak dalece ta atmosfera się rozwinęła, świadczy najlepiej sposób „epuracji” I pułku.

Mam powody do sądzenia, że były siły, które pracowały nad tym, żeby P.R. usunąć z pułku i w ogóle z Armii Polskiej dlatego, że sa oni ${ }^{36}$ wyćwiczonymi i doświadczonymi żołnierzami i podoficerami, że z ich usunięciem wojsko mniej zdatne będzie do boju i dłużej będzie musiało pozostawać na tyłach. Taką myśl wypowiedział jeden z badanych przez mnie P.R.

Armia polska była uważana przez niektórych ludzi za ucieczke przed pobytem na froncie. Część ludzi z armii francuskiej podszyła się pod polskość, żeby uwolnić się od służby na froncie. Ludzie ci zainteresowani sa w tym, żeby armia ta jak najdłużej była niezdatna do boju i żeby za taką była uważana przez sfery wojskowe francuskie. Dla tych właśnie ludzi przybywanie do wojska polskiego P.R., gotowych już żołnierzy i podoficerów, jest bardzo niepożądane i pracują oni nad tym, żeby się ich pozbyć.

Podobne intrygi, jak również wszelka szkodliwa agitacja w pułku ułatwione są przez to, że między dowódca pułku a jego ludźmi nie ma należytego związku i że dowódca, otoczony ludźmi, nie posiadającymi zaufania żołnierzy, nie ma sposobu zapoznania się z istotnym stanem umysłów w swoim pułku.

Powyższy stan rzeczy w I pułku strzelców, jak go odsłoniły opisane wyżej wypadki i przeprowadzona po nich ankieta, zaniepokoił wielce Komitet Narodowy i wskazał mu, że jego dotychczasowa ingerencja w sprawach armii polskiej nie jest dostateczna.

\footnotetext{
${ }^{35} \mathrm{~W}$ ich mniemaniu, domniemanego.

${ }^{36}$ Przekreślone: „najlepiej”.
} 